\title{
Nutritional effects, toxicity and haematology studies of the ethanolic root bark extract of Hymenocardia acida, Tul (Euphorbiaceae)
}

\author{
Paul N. Olotu ${ }^{1}$, Ijeoma A. Olotu ${ }^{2}$, Mighi B. Kambasha ${ }^{1}$, Abubakar Ahmed ${ }^{3}$, Ukpe Ajima ${ }^{4}$, Temitayo L. Ohemu ${ }^{1}$, \\ Victoria A. Okwori ${ }^{1}$, Dalen G. Dafam ${ }^{1}$, Francis M. Agwom ${ }^{4}$, Jane David ${ }^{5}$, Emmanuel U. Onche ${ }^{6}$ \\ ${ }^{1}$ Department of Pharmacognosy \& Traditional Medicine, Faculty of Pharmaceutical Sciences, University of Jos, PMB 2084, Jos, Nigeria. \\ ${ }^{2}$ Department of Biochemistry, Faculty of Medical Sciences, University of Jos, PMB 2084, Jos, Nigeria. \\ ${ }^{3}$ Department of Pharmacognosy and Drug Development, Faculty of Pharmaceutical Sciences, Ahmadu Bello University Zaria, Nigeria. \\ ${ }^{4}$ Department of Pharmaceutical Chemistry, Faculty of Pharmaceutical Sciences, University of Jos, PMB 2084, Jos, Nigeria. \\ ${ }^{5}$ Department of Medical Biotechnology, National Biotechnology Development Agency, Abuja, Nigeria. \\ ${ }^{6}$ School of Chemistry, University of Manchester, United Kingdom.
}

\section{ARTICLE INFO \\ Article history: \\ Received on: 16/08/2016 \\ Accepted on: 19/01/2017 \\ Available online: 30/04/2017}

\section{Key words:}

Nutrition, Acute toxicity, chronic toxicity,

Haematology, Hymenocardia acida.

\begin{abstract}
The plant Hymenocardia acida has been used traditionally for decades in Northern Nigeria for the management of different types of pain such as chest-pain, rheumatic pain, tooth ache etc. It is also claimed to be beneficial in the ethno-medicinal management of sickle cell anaemia. The present study evaluates the nutritional properties, toxicity and haematological profile of the ethanolic root bark extract of the plant. Investigation of the acute toxicity of the extract in mice showed it to be safe and well tolerated on oral administration even up to doses of $6,000 \mathrm{mg} / \mathrm{kg}$ body weight. Histopathological studies on chronic administration of the extract in mice showed no observable organ damage at low dose but at higher doses, a focal area of hepatic necrosis was observed. The globule cells of the intestine were covered with progressive mucin and lymphocyte proliferations were observed within the spleen. Analysis of the blood parameters showed very significant increase in red blood cell count. The results obtained provide a rational basis for some of the uses of the plant in traditional medicine practice.
\end{abstract}

\section{INTRODUCTION}

The plant Hymenocardia acida is a tree of about 6 meters in height, gnarled and twisted with characteristic rough, rusty-red bark. It is found in savannah region, scrub and open woodland typically in the tropical parts of Africa from Senegal to West Cameroons, and even beyond. The wood is light brown or pink, darkening to orange, close-grained, with conspicuous annual rings, and hard (Bouquet and Debray, 1974). The plant has been used traditionally for decades in various parts of Africa. For example, the Gbaya of the Central African Republic recognize the tree as producing good firewood (Bouquet, 1969). The tree is used for house-posts in southern Nigeria, and in Gabon where the wood is made into charcoal for blacksmith's

\section{* Corresponding Author}

Paul N Olotu, Department of Pharmacognosy \& Traditional Medicine, Faculty of Pharmaceutical Sciences, University of Jos, PMB 2084, Jos, Nigeria.Email: olotupauln@yahoo.com work. In Kenya and Uganda, the wood is known for its hardness, denseness, durability and good resistance to termite-attack and is used to make pestles and back-cloth mallets. Charcoal made from the branches is powdered and rubbed on the head for headache in the Soudanian region (Burkill, 1985). The foliage is consumed by cattle in Senegal and Nigeria as a supplementary food and the leaves and leafy shoots have been reported to have considerable medicinal use. Leaves are prepared into infusion for use in Senegal for chest complaints and small-pox and with the roots, for deficiency diseases. A macerate is given for gripe, and leafdecoction used as an eye wash (Dalziel, 1937). A decoction with honey is taken in Guinea for biliousness. In Ivory coast-upper Volta, a leaf-decoction is used in baths and draughts as a febrifuge and leaf-powder is taken as snuff for headache or applied topically for rheumatic pains and toothache, or for the same purposes, leaves may be pulped with organic acidic substances such as citron juice or sap of Piliostigma reticulatum (Kerharo, 1974). Phytochemical screening of the leaf extracts of Hymenocardia acida using water, 
ethanol and diethyl ether as extracting solvent revealed the presence of tannins, alkaloids saponins, terpenoids and flavonoids (Kamba and Hassan, 2010). The leaf extract was shown also to have inhibitory activity against Staphylococcus aureus, Salmonella typhii, E. coli and Klebsiela sp. (Kamba and Hassan, 2010). It has been reported that Hymenocardia acida leaf extract exerts pharmacological activity in rats, by interaction with antioxidant enzymes, reactive oxygen species and extra cellular calcium (Henrietta et al., 2010). Furthermore, it has been demonstrated that aqueous ethanolic extract of Hymenocardia acida stem bark in female rats has anti-fertility activity. The results suggest that, it could induce inhibitory effects on reproductive functions in female albino rats (Abu and Uchendu, 2011).Investigation of the antiinflammatory and anti-nociceptive activities of Hymenocardia acida showed that the extract also had a significant effect in the acute pain model as demonstrated in the tail immersion test. This was evidenced by increase in latency time. This effect of the extract indicates that it might be centrally acting and centrally acting analgesic drugs elevate pain threshold of animals towards heat and pressure (Adeyemi et al., 2004). The Hausa tribe in the Northern Nigeria has over the years used the decoction of leaves and stem bark or root bark of Hymenocardia acida in the treatment of pain of various categories such as migraine, sickle cell crisis and menstrual pain (Agishi, 2004). To the best of our knowledge, there is no report on the toxicity and haematological profile of the ethanolic root-bark extract of the plant to establish its safety scientifically. This study therefore aims at evaluating the nutritional benefits and the haematological profile as well as establishing the safety of the extract with a view to its future development.

\section{MATERIALS AND METHODS}

\section{Plant Collection and Identification:}

The plant material was collected from Kudingi village, Zaria, Nigeria. The plant was identified in the field using keys and description given in the official books (Woody Plant of West Tropical Africa). The collection (voucher specimen) was confirmed and authenticated at the Herbarium, Department of Biological Sciences, Ahmadu Bello University, Zaria (1010).

\section{Preparation of extract}

The root bark of Hymenocardia acida was cleaned and air dried at room temperature. The plant material was ground into a fine powder using a pestle and mortar. Extraction was carried out using cold maceration, where 80 grams of the powder was soaked in 4 Litres of $80 \% \mathrm{v} / \mathrm{v}$ ethanol for $72 \mathrm{~h}$; it was occasionally stirred with a glass stirrer throughout this period. The resultant mixture was filtered using Whatman filter paper (No.1) and the filtrate was concentrated to dryness in vacuo at $40{ }^{\circ} \mathrm{C}$ using a rotary evaporator.

\section{Animals}

Swiss albino mice $(100-200 \mathrm{~g})$ of either sex were obtained from the Animal House of Department of Pharmacology,
University of Jos, Jos, Nigeria, and were used for the experiments. Animals were maintained in well ventilated rooms. They were fed with standard feeds and water provided ad libitum. All experiments were carried out in accordance with the ethical guidelines of the Institutional Animal Care and Use Committee. Ethical permission was also sought and obtained from the same body.

\section{Acute Toxicity Studies}

The study was carried out in two phases using Lorkes method (1983). In the first phase, the mice of either sex were randomized into groups of three mice each and were administered doses of 10,100 and $1000 \mathrm{mg} / \mathrm{Kg}$ bodyweight of the extract orally. Mice were observed for signs of toxicity, including death over a period of 24 hours. In the second phase of the study doses of $2,000,4,000$ and $6,000 \mathrm{mg} / \mathrm{Kg}$ body weight of the extracts were given to three different groups of one mouse each orally based on the result of the first phase.

\section{Chronic Toxicity Studies}

The use of Hymenocardia acida in traditional medicine is normally a long term administration and this study also attempts to monitor the long term effect of this drug on the animal tissue and organs. Male Swiss albino mice aged 4-6 weeks were used and these were grouped into 3 of 6 mice each. The control group (1) was given un-amended diet and water. Whereas the treated $(2 \& 3)$ groups were given amended diets of $25 \% \mathrm{w} / \mathrm{w}$ and $50 \% \mathrm{w} / \mathrm{w}$ of the plant root bark respectively for 3 months. The pre and posttreatment water-intake and body weights of each mouse were daily recorded. At the end of the 3 months, the mice were sacrificed and their various organ weights recorded. The organs examined for histopathology include the liver, the kidney, the heart, the lung and the skin. The organs were fixed in $10 \%$ buffered neutral formalin for $72 \mathrm{~h}$ before processing. This was to maintain the tissues as it was in the ante-mortem before the post-mortem. The different tissues were then labeled and allowed to dehydrate in graded series of alcohol in the ascending order of $70 \%, 80 \%, 95 \%$ and $100 \%$ alcohol after which the tissues were cleared with xylene and impregnated with paraffin wax, separately embedded for sectioning with rotatory microtome and microtome knife. The tissues were then sectioned at 6- micro thick and were mounted on a clean and grease free slip and then dried in an oven. The stained slides were examined with the compound microscope at X40 objective and the results were recorded. This was repeated with the other 6 mice fed with $50 \%$ w/ w amended diet and the control group. This experiment was repeated for female albino mice.

\section{Haematology}

The experiment was aimed at evaluating the effects of the plant on blood parameters with the view of investigating the traditional claims of the plant in the treatment of sickle cell anaemia. The parameters observed were packed cell volume (PCV), mean haemoglobin concentration $(\mathrm{Hb})$, total red blood cell count (RBC count), total white blood cell count (WBC count), 
platelet count (PC) and differential white blood cell count encompassing: Neutrophil, lymphocyte, eosinophil, Basophils and Monocyte count. In the protocol, Swiss albino mice were fed with amended diet containing $25 \% \mathrm{w} /{ }_{\mathrm{w}}$ and $50 \% \mathrm{w} / \mathrm{w}$ of the root bark. After 65 days, the mice were euthanized and the blood parameters were evaluated using standard methods described by (Akinloye and Olorede, 2004). The results were compared with animals fed on unammended diet.

\section{Statistical analysis}

Results were expressed as Mean \pm Standard Error of Mean (SEM). Statistical analysis was done by analysis of variance (ANOVA).Values of $\mathrm{p} \leq 0.05$ were considered significant.

\section{RESULTS AND DISCUSSION}

\section{Acute toxicity studies}

The ethanolic root bark extract of Hymenocardia acida when administered orally was found to be safe. No death was recorded nor was any sign of toxicity observed within 24 hours of administration even at a higher dose of $6,000 \mathrm{mg} / \mathrm{kg}$ bodyweight. The $\mathrm{LD}_{50}$ being above than $5000 \mathrm{mg} / \mathrm{kg}$ body weight therefore implies that the extract is safe as suggested by Lorke (1983). Also, the absence of death among rats in all the dose groups throughout the study period of the experiment seems to support this claim.

\section{Chronic Toxicity Studies}

Over 90 days of the experimental studies, the mice fed with $25 \% \mathrm{w} / \mathrm{w}$ amended diet did not show any observable tissue damage in the lungs, hearts, kidneys, brain, intestines and spleens. The control mice also showed no visible liver damage but the mice fed with $50 \%{ }^{\mathrm{w}} / \mathrm{w}$ amended diet reacted differently. They showed a focal area of hepatic necrosis and the globule cells of the intestine were covered with progressive mucin and lymphocyte proliferations were observed with the spleen. The results are presented in plates 1 to 4 below. On the other hand, no tissue damage was observed on the pancreas, hearts, lungs, kidneys and brain. It can therefore be inferred that prolonged (chronic) treatment with this plant drug in traditional medicine should proceed cautiously.

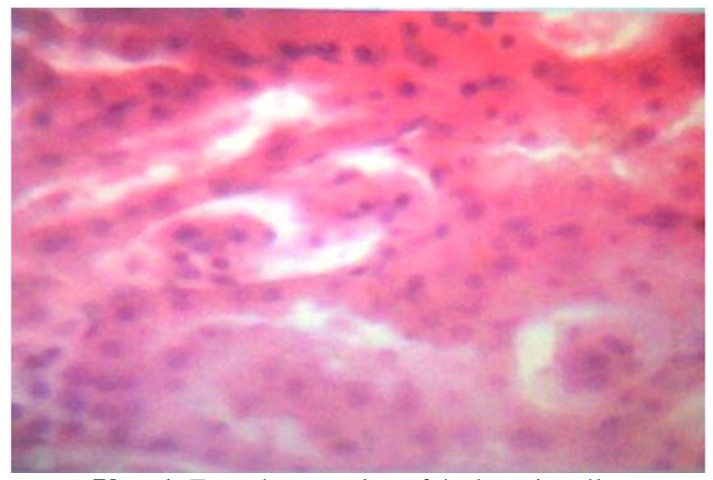

Plate 1: Fatty degeneration of the hepatic cells

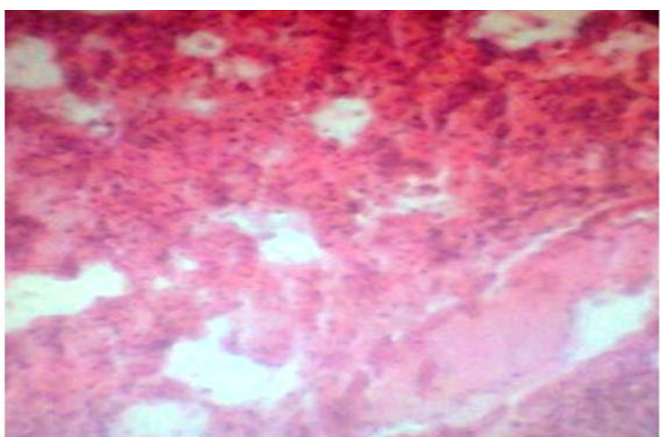

Plate 2: Necrosis of Hepatic cells

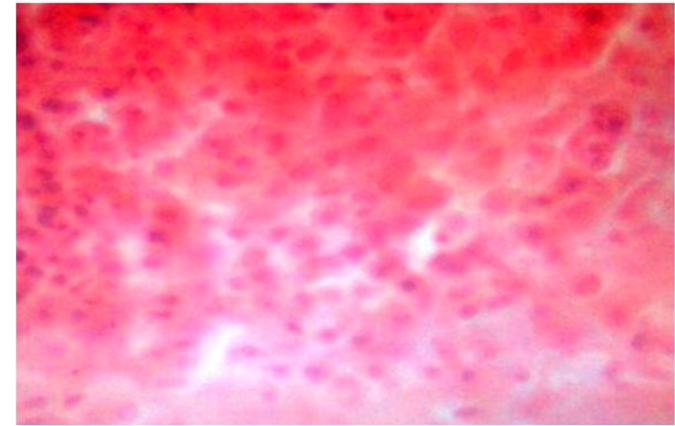

Plate 3: Progressive mucin seen on the globule cells of the intestine.

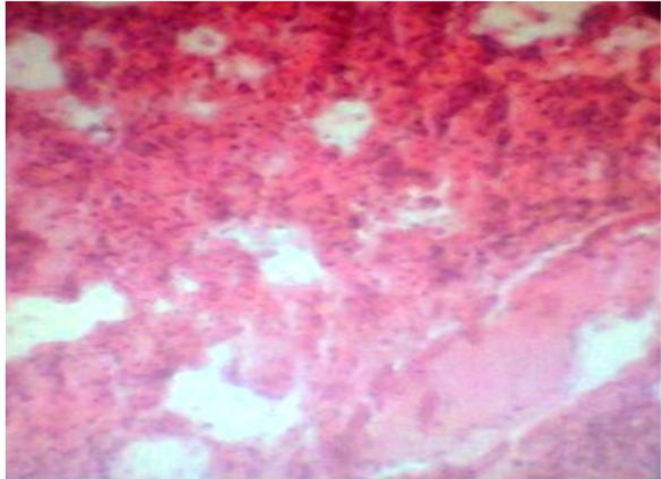

Plate 4: The section of the spleen showing lymphocyte proliferation

\section{Nutritional Effects}

The body weight, feed and water-intake increase with the mice fed with the lower concentration of the amended diet $(25 \%$ $\mathrm{w} / \mathrm{w}$ ) but decreased with the higher concentration $(50 \% \mathrm{w} / \mathrm{w})$. There was also a prominent change with the post treated mice. This result may suggest the use of the plant for nutritional purposes at lower concentration.

\section{Haematology studies}

Analysis of the blood parameters showed very significant increase in the red blood cells (RBC) (Table 1) and this may increase oxygen delivery to the body cells and tissues which is beneficial in anaemia and this may justify the claims about the use of the plant in the management of sickle cell anaemia. Analysis of the effects of the extract on the remaining blood parameters showed no significant differences (Table '1). In addition, there were slight decreases in the differential white blood cell count as shown in table 2 . 
Table 1: Effects of ethanolic root bark extract of Hymenocardia acida on Haematological parameters.

\begin{tabular}{|c|c|c|c|c|c|}
\hline Treatment Groups & $\operatorname{PCV}(\%)$ & Haemoglobin (g/dl) & $\mathbf{R B C}\left(\mathrm{mm}^{3}\right)$ & $\mathrm{WBC}\left(\mathrm{mm}^{3}\right)$ & Platelet $\left(\mathrm{mm}^{3}\right)$ \\
\hline Un-amended diet (A) & $34.80 \pm 0.44$ & $11.00 \pm 0.31$ & $5.89 \pm 0.09$ & $6544.00 \pm 114.02$ & $146200.00 \pm 835.77$ \\
\hline Amended Diet treated with $25 \%$ extract (B) & $29.00 \pm 0.22$ & $07.00 \pm 0.62$ & $6.12 \pm 0.18^{\mathrm{a}}$ & $4140.00 \pm 114.02$ & $118200.00 \pm 846.55$ \\
\hline Amended Diet treated with $50 \%$ extract (C) & $30.20 \pm 1.50$ & $08.11 \pm 0.15$ & $10.02 \pm 0.29^{\mathrm{a}}$ & $4548.00 \pm 164.02$ & $124120.00 \pm 99277.00$ \\
\hline
\end{tabular}

Values are mean \pm SEM for five determinations $(n=5)$

$\mathrm{a}=$ significantly different from control (unamended diet) at $\mathrm{p}<0.05$.

Table 2: Effects of ethanolic root bark extract of Hymenocardia acida on WBC differentials.

\begin{tabular}{|c|c|c|c|c|c|}
\hline Treatment Groups & Neutrophil (\%) & Lymphocyte (\%) & Eosinophil (\%) & Basophil (\%) & Monocyte (\%) \\
\hline Un-amended diet (A) & $33.00 \pm 0.62$ & $64.07 \pm 0.77$ & $2.90 \pm 0.11$ & $0.00 \pm 0.00$ & $4.00 \pm 0.11$ \\
\hline Amended Diet treated with $25 \%$ extract (B) & $21.00 \pm 0.32^{\mathrm{a}}$ & $55.60 \pm 1.23^{\mathrm{a}}$ & $0.60 \pm 0.23^{\mathrm{a}}$ & $0.00 \pm 0.00$ & $2.60 \pm 0.78^{\mathrm{a}}$ \\
\hline Amended Diet treated with $50 \%$ extract (C) & $22.20 \pm 1.90^{\mathrm{a}}$ & $57.60 \pm 1.44^{\mathrm{a}}$ & $0.80 \pm 0.11^{\mathrm{a}}$ & $0.00 \pm 0.00$ & $2.61 \pm 0.77^{\mathrm{a}}$ \\
\hline
\end{tabular}

Values are mean \pm SEM for five determinations $(n=5)$,

$\mathrm{a}=$ significantly different from control (unamended diet) at $\mathrm{p}<0.05$.

\section{CONCLUSION}

The study has revealed that the ethanolic root bark extract of Hymenocardia acida is safe showing very little toxicity and has beneficial nutritional constituents. Further studies on this plant will involve isolation and characterization of the constituents responsible for the observed increase in red blood cell numbers. The results obtained also support the use of this plant in traditional medicine particularly in sickle cell anemia management.

\section{Financial support and sponsorship: NIL.}

Conflict of Interests: There are no conflicts of interest.

\section{REFERENCES}

Abu AH and Uchendu CN. Safety assessments of Aqueous Ethanolic Extract of Hymenocardia acida Stem bark in Wister Rats. Arch App Sci Res, 2010; 2 (5): 56 - 68

$\mathrm{Abu} \mathrm{AH}$ and Uchendu CN. Antifertility Activity of Aqueous Ethanolic Extract of Hymenocardia acida stem bark in Female Rats. Iranian J Reproduc Med, 2011; 9 (3): 217 - 222.

Adeyemi YC, Sofidiya MO, Odukoya OA, Adedapo AA, Mbagwu HOC, Afolayan AJ and Familoni OB. Investigation of AntiInflammatory and Antinociceptive Activities of Hymenocardia acida, Tul. Afr J Biotech, 2004; 9 (49): 8459 - 8470.

Agishi EC. 2004. Etulo, Idoma, Igede, Tiv and Hausa names of Plants. Makurdi, Nigeria: AGITAB Publishers Ltd.

Bouquet A and Debray M. 1974. Medicinal plants of the Ivory Coast. France. Trav. Doc. Orst 32:
Bouquet A. 1969. Medicinal Plants of the Ivory Coast. France: Trav. Doc. Orst.

Burkill HM. 1985. The Useful Plants of West Tropical Africa, $2^{\text {nd }}$ Edition, Vol.1.Royal Botanic Gardens, Kew.

Dalziel JM. 1937. Useful plants of Tropical West Africa. London, United Kingdom: Crown Agent for Overseas Government and Administration.

Henrietta O, Oluwatoyin S, Joy O, Magdalene K, Benedicta A and Anthony E. Effect of Extracts of Hymenocardia acida Tul (Euphorbiaceae) on Rats. J Am Sci, 2010; 6 (2): 123 - 125.

Kamba AS and Hassan LG. Phytochemical and Microbial Screening of Hymenocardia acida leaves. Int J Pharm Frontier Res, 2011; 1 (1): 32 - 41 .

Kerharo J. 1974. Historic and Ethnopharmacognosic review on the belief and Traditional practices in the treatment of sleeping sickness in West Africa, Bull Soc. Med. Afri. Noire Lang. FR. 19: (Fac. Med. \& Pharm Dakar Senegal).

Lorke DA. A new Approach to Practical Acute Toxicity Testing. Arch. Toxicol, 1983; 54:275-287.

\section{How to cite this article:}

Olotu PN, Olotu IA, Kambasha MB, Ahmed A, Ajima U, Ohemu TL, Okwori VA, Dafam DG, Agwom FM, David J, Onche EU. Nutritional effects, toxicity and haematology studies of the ethanolic root bark extract of Hymenocardia acida, Tul (Euphorbiaceae). J App Pharm Sci, 2017; 7 (04): 111-114. 